\title{
Synthesis and Biological Evaluation of Xanthine Derivatives on Dipeptidyl Peptidase 4
}

\author{
Kuaile Lin, Zhengyan Cai, Fei Wang, Wei Zhang, and Weicheng Zhou* \\ State Key Lab of New Drug \& Pharmaceutical Process, Shanghai Key Lab of Anti-Infectives, Shanghai Institute of \\ Pharmaceutical Industry, State Institute of Pharmaceutical Industry; Shanghai 200437, China. \\ Received December 6, 2012; accepted January 12, 2013; advance publication released online January 28, 2013
}

\begin{abstract}
A series of xanthine derivatives in which a methylene was inserted at position 8 of xanthine scaffold was synthesized and evaluated as inhibitors of dipeptidyl peptidase 4 (DPP-4) for the treatment of type 2 diabetes. As the results of structure-activity relationship (SAR) study of the series, the compounds with 4-methylquinazoline-2-yl-methyl group at N-1 position and 2-aminoethylaminomethyl group gave better activities. Compounds H4 and H9 showed good DPP-4 inhibition and more than 100-fold selectivity over DPP-7 and DPP-8.
\end{abstract}

Key words dipeptidyl peptidase; dipeptidyl peptidase 4 inhibitor; xanthine

Diabetes is establishing itself as a serious epidemic of the 21st century. Data from global studies demonstrates that the number of people suffering from the disease in 2011 has reached a staggering 366 million, including 4.6 million deaths, and the health care spending on diabetes has reached 464 billion dollars. ${ }^{1)}$ Type 2 diabetes (T2D), formerly noninsulindependent diabetes, accounts for at least $90 \%$ of all cases of the disease. ${ }^{1)}$ Inhibition of dipeptidyl peptidase 4 (DPP-4) has proven to be an effective treatment for improving glycemic control in type 2 diabetic patients. ${ }^{2}$ DPP-4 cleaves a wide range of peptides to modulate their biological activity. One of these peptides is glucagon-like peptide 1 (GLP-1), which plays an important role in the regulation of blood glucose level. ${ }^{3)}$ GLP-1 is released after food ingestion and stimulates insulin biosynthesis and secretion. GLP-1 also inhibits glucagon release, delays gastric emptying, and induces pancreatic $\beta$-cell proliferation. ${ }^{4}$

In recent years, a number of DPP-4 inhibitors, such as sitagliptin (1), vildagliptin (2), saxagliptin (3), alogliptin (4) and linagliptin (5) (Fig. 1) have been launched and showed great efficacy in patients with T2D. Linagliptin (5), with the xanthine scaffold, has been proved as a highly potent and selective DPP-4 inhibitor. ${ }^{5)}$ The X-ray crystal structure of linagliptin in the complex with human DPP-4 showed that the aminopiperidine at $\mathrm{C}-8$ of the xanthine scaffold occupied the S2 subsite. Its primary amine formed a network of chargereinforced hydrogen bonds to Glu205, Glu206 and Tyr662, the residues that constitute the recognition site for the amino terminus of DPP-4. The butynyl substituent at N-7 occupied the hydrophobic S1 pocket of the enzyme. The xanthine moiety laid on top of Tyr547, forming aromatic $\pi$-stacking interactions with the phenol of Tyr547. The quinazoline substituent at N-1 interacted with Trp629 by $\pi$-stacking interactions. ${ }^{5)}$ So far, most of existing reports on the structural modifications of xanthine derivatives were focused on the substituents at $\mathrm{N}-1$, $\mathrm{N}-7$, and the xanthine scaffold. ${ }^{5-10)}$ In this paper, a series of new xanthine derivatives in which a methylene was inserted at position 8 in xanthine scaffold were designed, illustrated as formula $\mathbf{H}$ (Table 1). And molecular docking between the target compounds and DPP-4 was studied with the molecular modeling software Discovery Studio 2.5 (Accelrys, Inc.). As shown in Fig. 2, compound H6 bound to DPP-4 in very<smiles>N[C@@H](CC(=O)N1CCn2c(nnc2C(F)(F)F)C1)Cc1cc(F)c(F)cc1F</smiles><smiles>Cn1c(=O)cc(N2CCC[C@@H](N)C2)n(Cc2ccccc2C#N)c1=O</smiles>

alogliptin, 4<smiles>N#C[C@@H]1CCCN1C(=O)CNC12CC3CC(CC(O)(C3)C1)C2</smiles>

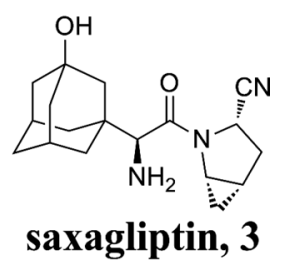<smiles>CC#CCn1c(N2CCCC(N)C2)nc2c1c(=O)n(Cc1nc(C)c3ccccc3n1)c(=O)n2C</smiles>

linagliptin, 5

Fig. 1. Structures of Launched DPP-4 Inhibitors 
Table 1. The DPP-4 Inhibitory Activity of H1-H45

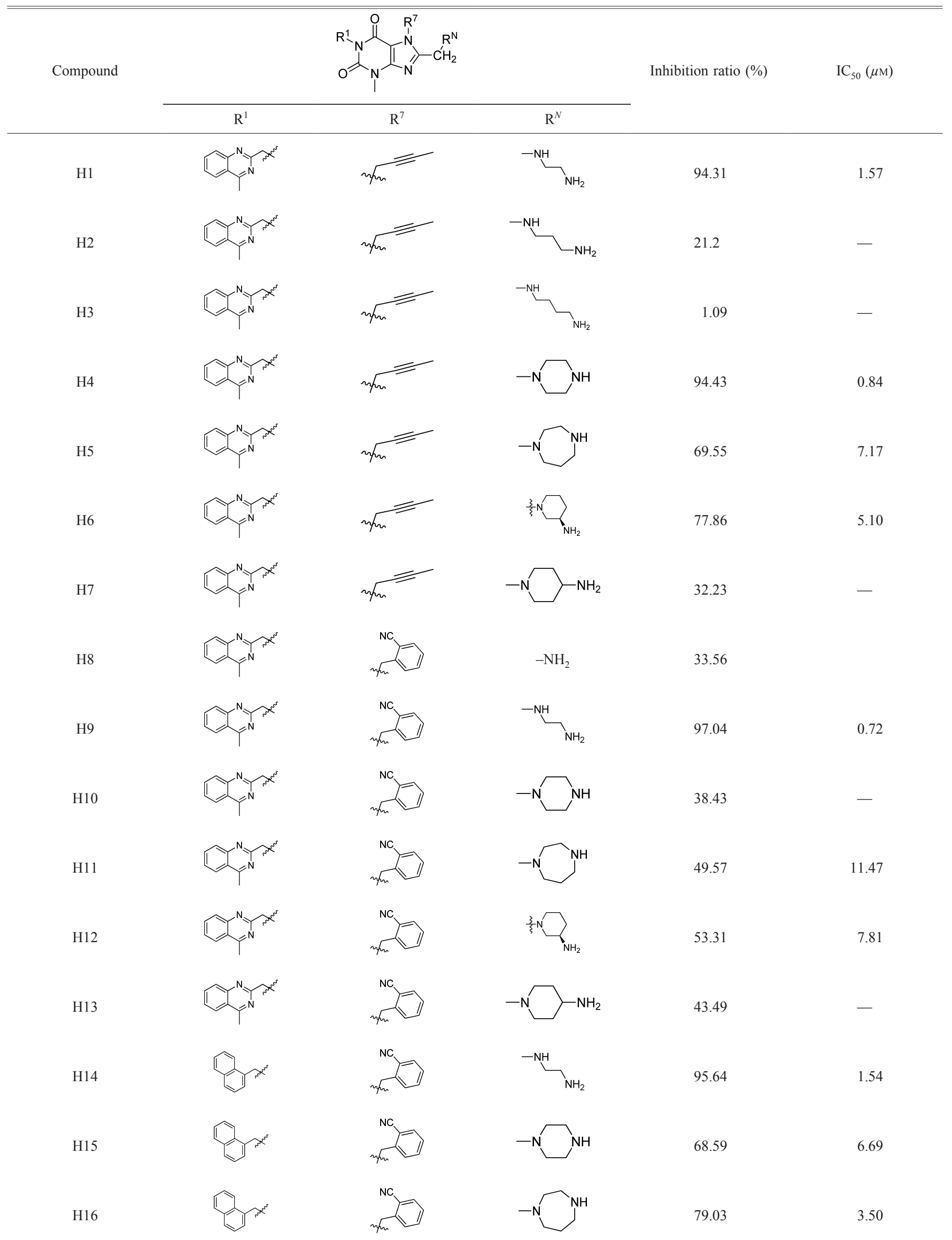


Table 1. The DPP-4 Inhibitory Activity of H1-H45

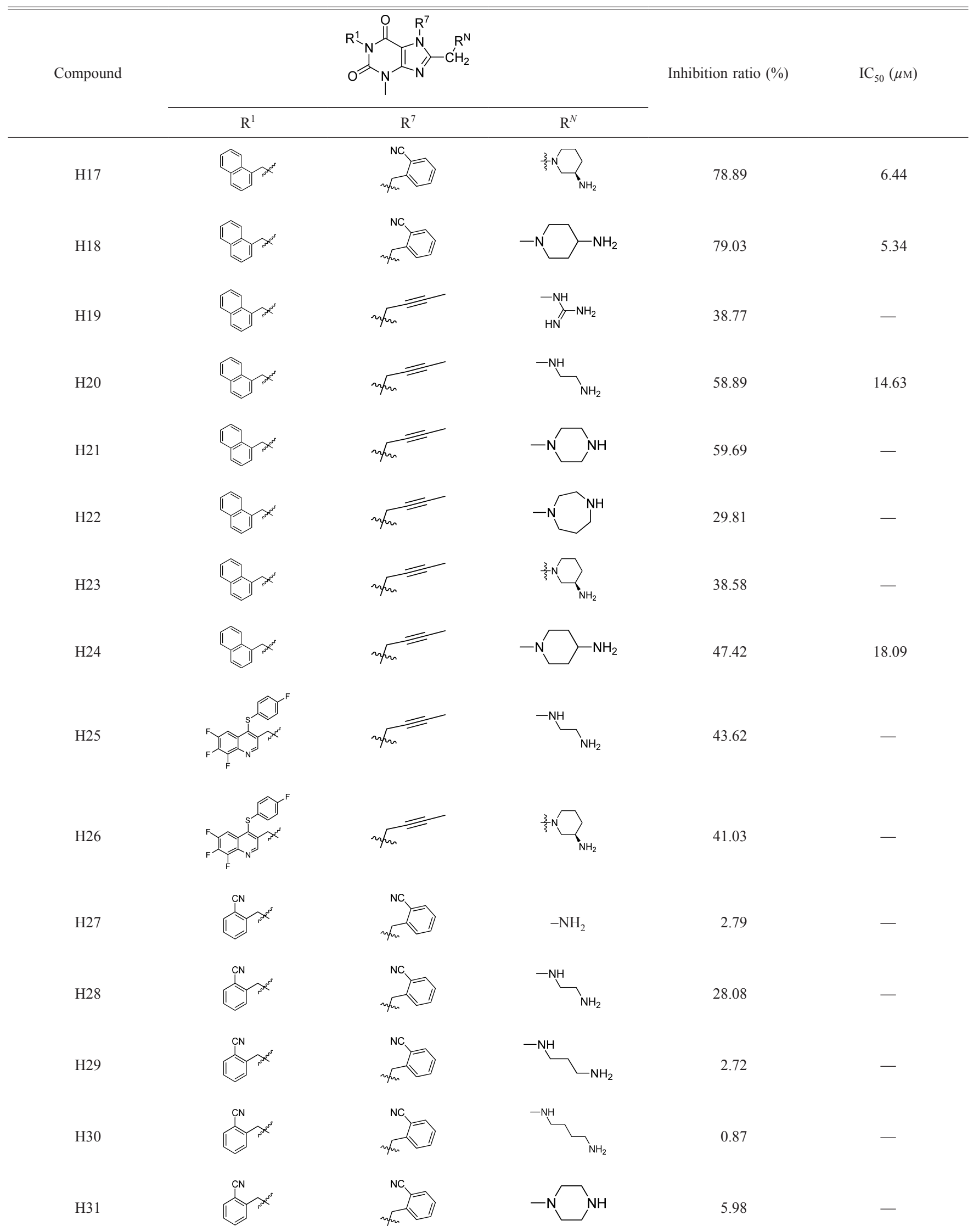


Table 1. The DPP-4 Inhibitory Activity of H1-H45

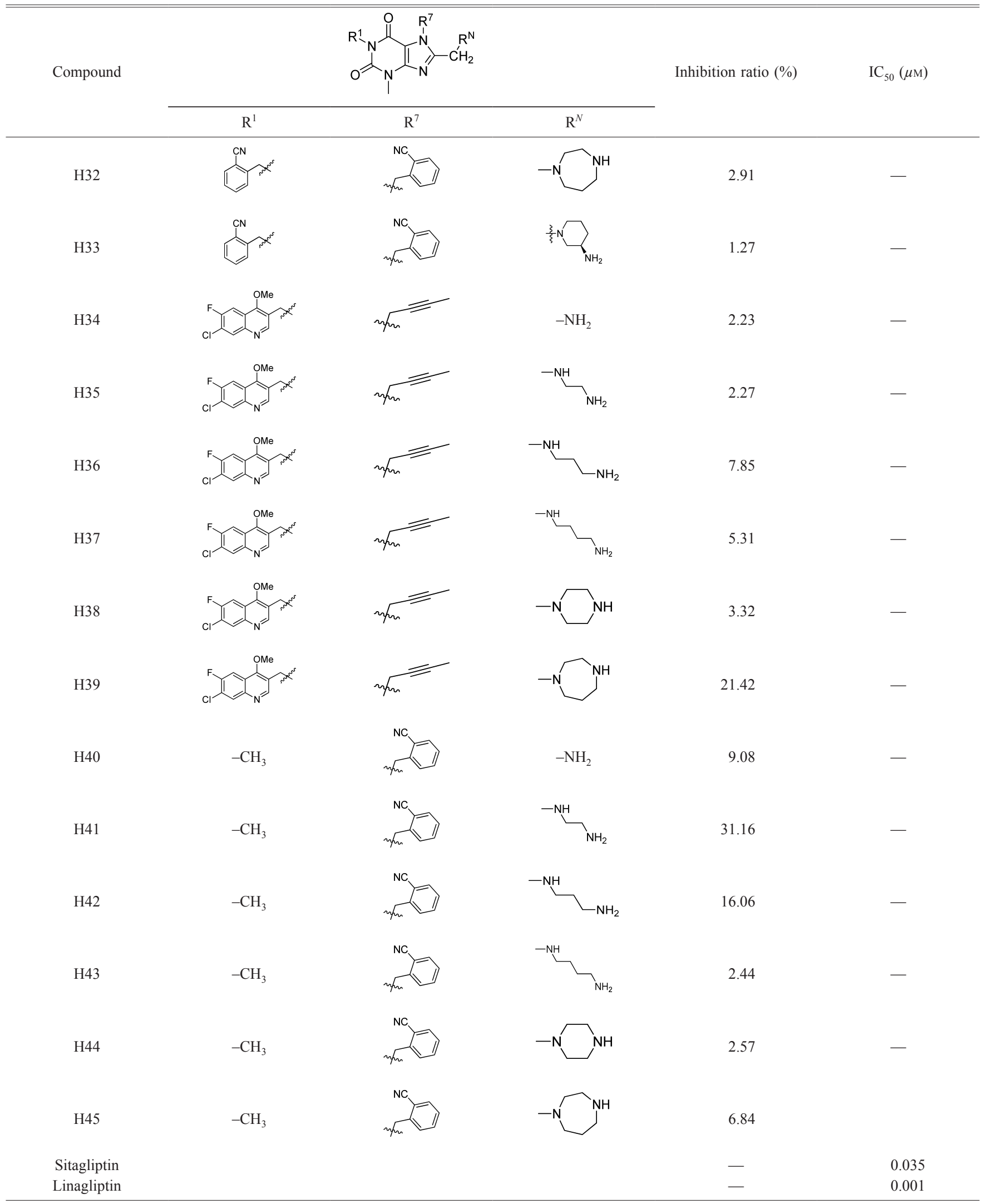




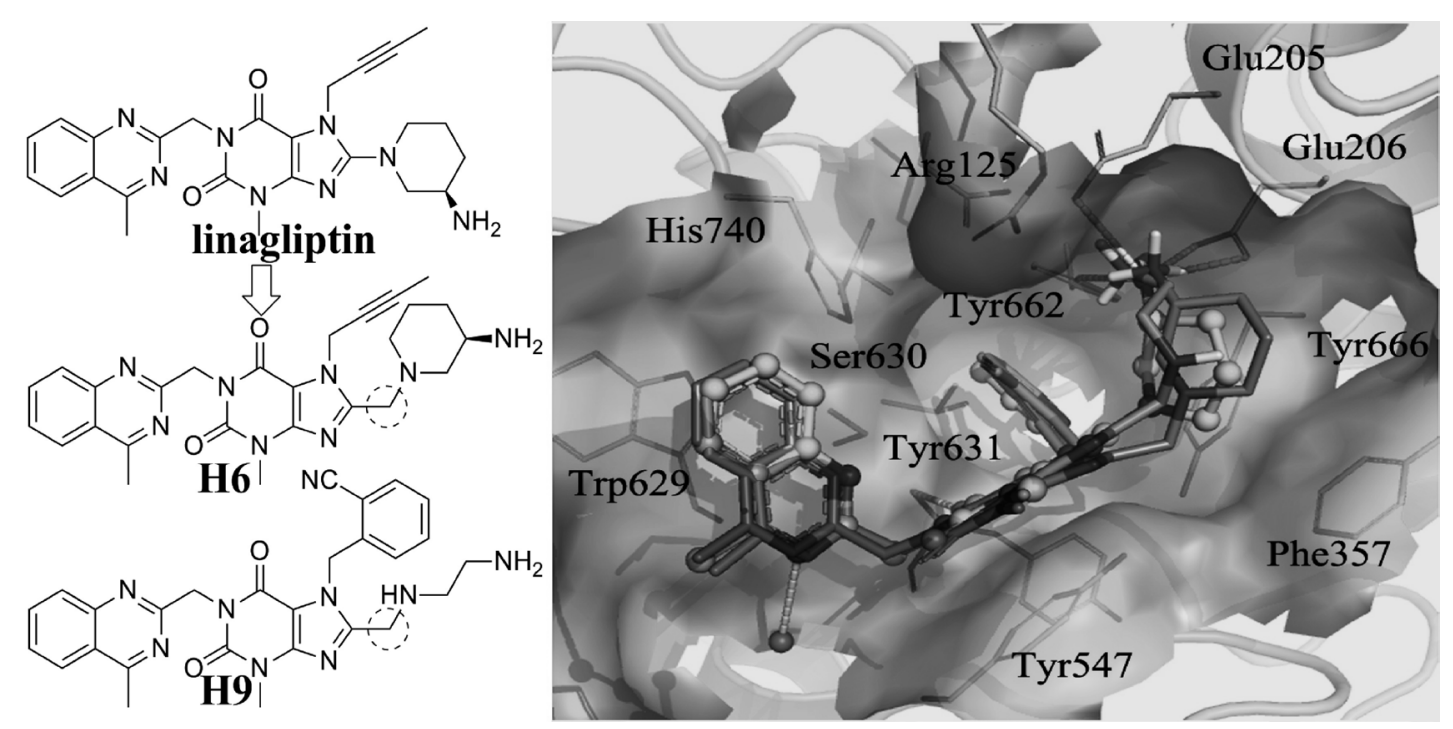

Fig. 2. Docking Modes of Compounds $\mathbf{H 6}$ (Blue) and H9 (Magenta) Overlaid with the Bound Conformation of Linagliptin (Cyan, PDB Entry 2RGU) Color image was converted into gray scale.

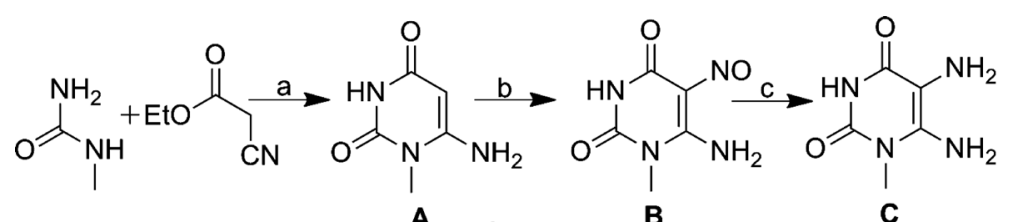

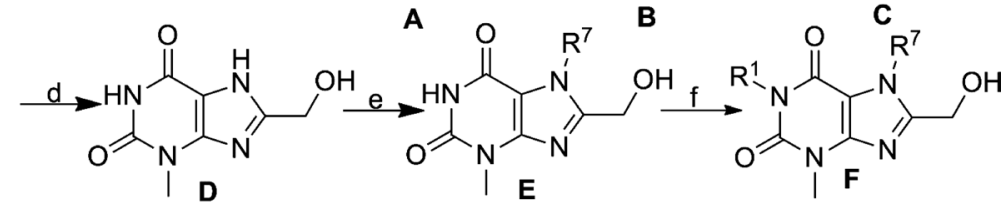<smiles>[R1]Cc1nc2c(c(=O)n([R1])c(=O)n2C)n1[R1]</smiles>

Reagents and conditions: (a) $\mathrm{Na}$, EtOH, 70\%; (b) $\mathrm{NaNO}_{2}, \mathrm{AcOH}, \mathrm{H}_{2} \mathrm{O}, 75 \%$; (c) $\mathrm{Na}_{2} \mathrm{~S}_{2} \mathrm{O}_{4}$, ammonium hydroxide, 96\%; (d) i) glycolic acid, $\mathrm{H}_{2} \mathrm{O}$, ii) $\mathrm{NaOH}$, $\mathrm{H}_{2} \mathrm{O}$, 79\%; (e) $\mathrm{R}^{7} \mathrm{X}\left(\mathrm{X}=\mathrm{Cl}\right.$ or Br), DIEA, DMSO, 53-82\%; (f) $\mathrm{R}^{1} \mathrm{X}\left(\mathrm{X}=\mathrm{Cl}\right.$ or $\mathrm{Br}$ ), $\mathrm{K}_{2} \mathrm{CO}_{3}, \mathrm{DMF}, 30-89 \%$; (g) $\mathrm{MeSO}_{2} \mathrm{Cl}_{2} \mathrm{Et}_{3} \mathrm{~N}, \mathrm{CH}_{2} \mathrm{Cl}_{2}, 30-95 \%$; (h) $\mathrm{R}^{N} \mathrm{H}, \mathrm{CH}_{2} \mathrm{Cl}_{2} \mathrm{or}$ i) $\mathrm{R}^{N} \mathrm{H}, \mathrm{CH}_{2} \mathrm{Cl}_{2}$, $\mathrm{Et}_{3} \mathrm{~N}$; ii) $\mathrm{CF}_{3} \mathrm{COOH}, \mathrm{CH}_{2} \mathrm{Cl}_{2}, 32-97 \%$.

Chart 1

similar mode as linagliptin. So 45 novel xanthine derivatives were synthesized and their inhibition on DPP-4 was evaluated.

\section{Results and Discussion}

Chemistry The synthesis of new xanthine derivatives was shown in Chart 1. Condensation of methylurea and ethyl cyanoacetate followed by nitrosation gave compound $\mathbf{B}^{11)}$ Reduction of nitroso group with sodium hydrosulfite yielded compound $\mathbf{C}^{12)}$ The xanthine ring was formed by the condensation of compound $\mathbf{C}$ with glycolic acid. The alkylation at $\mathrm{N}-7$ position was carried out by treatment with $\mathrm{R}^{7} \mathrm{X}(\mathrm{X}=\mathrm{Cl}$ or $\mathrm{Br}$ ) and diisopropylethylamine in dimethyl sulfoxide (DMSO). The compounds $\mathbf{E}$ were further alkylated at $\mathrm{N}-1$ position with $\mathrm{R}^{1} \mathrm{X}(\mathrm{X}=\mathrm{Cl}$ or $\mathrm{Br})$ and potassium carbonate in $\mathrm{N}, \mathrm{N}$ dimethylformamide (DMF). The activation of the hydroxy with methanesulfonyl chloride gave methylsulfonate G. The target products were achieved through nucleophilic substitution by amines. All the structures of target compounds were confirmed by ${ }^{1} \mathrm{H}-\mathrm{NMR}$ and MS.
Biological Activity DPP-4 was extracted from confluent Sf9 cell. The activity was measured as described, ${ }^{13,14)}$ using the substrate Gly-Pro- $p$-nitroanilide, which can be decomposed to Gly-Pro and $p$-nitroaniline by DPP-4. Compounds H1-H45 were dissolved in $1 \%$ DMSO aqueous solution and were tested at a fixed level of $10 \mu \mathrm{g} / \mathrm{mL}$. The compounds with the inhibition rate over $50 \%$ went through into the second round of screening where the inhibitory concentration $50 \%\left(\mathrm{IC}_{50}\right)$ was determined and the result was included in Table 1. Among the compounds in the first round testing, 14 compounds were found to possess moderate or significant activity. In the second screening, compounds H1, H4, H9 and H14 showed the best inhibitory activity. In order to confirm the results as well as to study the selectivity among DPP-4, DPP-7 and DPP-8, compounds H4, H9 and H14 were sent to the National Center for Drug Screening for the selective inhibition testing. The data were given in Table 2. As far as structure-activity relationship (SAR) was concerned, variations at N-1 position showed that the 4-methyl-quinazolin-2-yl-methyl (H1-H13) 
Table 2. The DPP-4, DPP-7 and DPP-8 Inhibitory Activity of H4, H9 and H14

\begin{tabular}{|c|c|c|c|c|c|c|}
\hline \multirow[b]{2}{*}{ Compound } & \multicolumn{2}{|c|}{ DPP-4 } & \multicolumn{2}{|c|}{ DPP-7 } & \multicolumn{2}{|c|}{ DPP-8 } \\
\hline & $\begin{array}{c}\text { Inhibition ratio at } \\
20 \mu \mathrm{g} / \mathrm{mL}\end{array}$ & $\mathrm{IC}_{50}(\mu \mathrm{M})$ & $\begin{array}{c}\text { Inhibition ratio at } \\
250 \mu \mathrm{g} / \mathrm{mL}\end{array}$ & $\mathrm{IC}_{50}(\mu \mathrm{M})$ & $\begin{array}{c}\text { Inhibition ratio at } \\
250 \mu \mathrm{g} / \mathrm{mL}\end{array}$ & $\mathrm{IC}_{50}(\mu \mathrm{M})$ \\
\hline H4 & $92.54 \%$ & 3.08 & $14.43 \%$ & $>530$ & $63.21 \%$ & 314 \\
\hline H9 & $92.29 \%$ & 2.66 & $37.36 \%$ & $>491$ & $68.26 \%$ & 223 \\
\hline H14 & $86.92 \%$ & 5.34 & $87.61 \%$ & 58.9 & $97.30 \%$ & 63.8 \\
\hline
\end{tabular}

and $\alpha$-naphtylmethyl (H14-H24) substitutions exhibited better inhibitory effect for DPP-4 than 6,7,8-trifluoro-4-(4fluorophenylthio)quinoline-3-yl-methyl, methyl, 2-cyanobenzyl or 6-fluoro-7-chloro-4-methoxyquinoline-3-yl-methyl substitution; and it seemed that compounds with 4-methyl-quinazoline-2-yl-methyl substitution gave better selectivity than those with $\alpha$-naphtylmethyl group (Table 2). At N-7 position, both 2-cyanobenzyl (H8-H13) and but-2-ynyl substitution (H1H7) performed similar effects on the activity. For $\mathrm{R}^{N}$ compounds, 2-aminoethylamino group was better for the inhibitory activity than its homologues $(\mathrm{H} 1>\mathrm{H} 2$ and $\mathrm{H} 3, \mathrm{H} 9>\mathrm{H} 8)$ in all the series, indicating that the preferable distance between two nitrogen atoms might be equivalent to two $\mathrm{CH}_{2}$. For the compounds with the ring substitutions, some active compounds were found in piperazinyl, homopiperazinyl and 3(R)aminopiperidinyl substitution in which the distance between two nitrogen also was two $\mathrm{CH}_{2}$. In most cases, flexible chain (2-aminoethylamino) seemed better than the rigid ring (piperazinyl, homopiperazinyl and 3(R)-aminopiperidinyl).

In beginning of the work, molecular docking strategy was used to investigate the binding mode of linagliptin and guide the procedure of molecular modification. Based on these preliminary docking results, comparable biological activities were expected. However, validated by bioassay, this series of compounds bear far lower binding affinities than linagliptin against DPP-4, for example, compound H6 which was very similar to linagliptin did not give potent activity, indicating the limit of molecular modeling strategy. In another hand, when compound $\mathbf{H 9}$, the most active one in this series, was taken into the molecular docking (Fig. 2), it was found that H9 bound to DPP-4 in a pose more matched with the linagliptin scaffold. In addition, 2-cyano benzyl bound to the conserved hydrophobic pocket might contribute a more favorable binding mode.

\section{Conclusion}

In summary, a novel class of DPP-4 inhibitors, derived from a xanthine scaffold, has been identified. The compounds with 4-methyl-quinazoline-2-yl-methyl group at N-1 position and 2-aminoethylaminomethyl group at $\mathrm{R}^{N}$ showed better activities. Compounds $\mathbf{H 4}$ and $\mathbf{H 9}$ showed good DPP-4 inhibition and more than 100-fold selectivity over DPP-7 and DPP-8, which were worthy to the further modification and research.

Supporting Information Full experimental details, physical and spectral data of the compounds $\mathbf{A}-\mathbf{H}$. This material can be found via article's webpage.

Acknowledgements This work was supported by 973 program of the Ministry of Science and Technology of China (2010CB735601 and 2012CB724501). We thank the National Center for Drug Screening for the selective inhibition testing on DPP-4 over DPP-7 and DPP-8.

\section{References}

1) International Diabetes Federation. "Diabetes Estimates Excel Tables": 〈http://www.idf.org/diabetesatlas/diabetes-estimates-tables», cited 22 May, 2012.

2) Mclntosh C. H. S., Front. Biosci., 13, 1753-1773 (2008).

3) Kieffer T. J., McIntosh C. H., Pederson R. A., Endocrinology, 136, 3585-3596 (1995).

4) Farilla L., Hui H., Bertolotto C., Kang E., Bulotta A., Di Mario U., Perfetti R., Endocrinology, 143, 4397-4408 (2002).

5) Eckhardt M., Langkopf E., Mark M., Tadayyon M., Thomas L., Nar H., Pfrengle W., Guth B., Lotz R., Sieger P., Fuchs H., Himmelsbach F., J. Med. Chem., 50, 6450-6453 (2007).

6) Kurukulasuriya R., Rohde J. J., Szczepankiewicz B. G., Basha F., Lai C., Jae H. S., Winn M., Stewart K. D., Longenecker K. L., Lubben T. W., Ballaron S. J., Sham H. L., von Geldern T. W., Bioorg. Med. Chem. Lett., 16, 6226-6230 (2006).

7) Nishio Y., Kimura H., Sawada N., Sugaru E., Horiguchi M., Ono M., Furuta Y., Sakai M., Masui Y., Otani M., Hashizuka T., Honda Y., Deguchi J., Nakagawa T., Nakahira H., Bioorg. Med. Chem., 19, 5490-5499 (2011).

8) Eckhardt M., Hauel N., Himmelsbach F., Langkopf E., Nar H., Mark M., Tadayyon M., Thomas L., Guth B., Lotz R., Bioorg. Med. Chem. Lett., 18, 3158-3162 (2008).

9) Nishio Y., Kimura H., Tosaki S., Sugaru E., Sakai M., Horiguchi M., Masui Y., Ono M., Nakagawa T., Nakahira H., Bioorg. Med. Chem. Lett., 20, 7246-7249 (2010).

10) Sutton J. M., Clark D. E., Dunsdon S. J., Fenton G., Fillmore A., Harris N. V., Higgs C., Hurley C. A., Krintel S. L., MacKenzie R. E., Duttaroy A., Gangl E., Maniara W., Sedrani R., Namoto K., Ostermann N., Gerhartz B., Sirockin F., Trappe J., Hassiepen U., Baeschlin D. K., Bioorg. Med. Chem. Lett., 22, 1464-1468 (2012).

11) Elzein E., Kalla R. V., Li X. F., Perry T., Gimbel A., Zeng D. W., Lustig D., Leung K., Zablocki J., J. Med. Chem., 51, 2267-2278 (2008)

12) Balssa F., Bonnaire Y., J. Labelled Compd. Radiopharm., 50, 33-41 (2007).

13) Nagatsu T., Hino M., Fuyamada H., Hayakawa T., Sakakibara S., Nakagawa Y., Takemoto T., Anal. Biochem., 74, 466-476 (1976).

14) Pascual I., Lopéz A., Gómez H., Chappé M., Saroyán A., González Y., Cisneros M., Charli J. L., Chávez M. A., Enzyme Microb. Technol., 40, 414-419 (2007). 